\title{
Immunodeficiency with Hyper-IgM Type 2
}

National Cancer Institute

\section{Source}

National Cancer Institute. Immunodeficiency with Hyper-IgM Type 2. NCI Thesaurus.

Code C129074.

An autosomal recessive immunodeficiency that is caused by mutation(s) in the AICDA gene, single-stranded DNA cytosine deaminase. It is characterized by normal or elevated concentrations of Ig M and decreased or absent concentrations of IgG, IgA, and IgE. 